\title{
E-Commerce Design for Palembang Home Tailors
}

\author{
Irma Salamah", Ciksadan ${ }^{1}$, Riska Melyani ${ }^{1}$ \\ ${ }^{1}$ Teknik Telekomunikasi, Politeknik Negeri Sriwijaya \\ irma.salamah@yahoo.com,cik_sadan@yahoo.com,riskamelyani@gmail.com
}

\begin{abstract}
Home tailors are SMEs that are business opportunities that are usually chosen by housewives because, being a home tailor can be a solution for housewives to keep earning even though they are at home. The problems faced are in marketing and promoting home tailoring services because usually the target customers are only the surrounding environment, therefore innovation in promotion strategies is needed, the use of modern technology such as E-Commerce can be a strategy in business, so that it can be known to the wider community. Responsive Web-based E-Commerce design for ordering and purchasing information systems in increasing the income of home-tailor SMEs, to design this information system The programming language that will be used is PHP, and MySql as a database.
\end{abstract}

Keywords: SMEs, E-Commerce, Web Responsive, PHP, MySql, Database

\section{Introduction}

SMEs becomes an important role in improving the economic income of the community, the difficulty of finding jobs requires the community to be more creative in order to open jobs, this is what makes SMEs the choice of the community to remain income, one of the SMEs that is currently potentially home-based SMEs, This choice of SMEs is usually chosen by housewives.

Becoming a home tailor is the best choice for housewives who can still earn even though they are at home, and can still do homework and work in the house, but the problems faced by these SMEs are, in marketing and promoting home tailoring services.

The target of home-tailor customers is usually only the community around the house or neighbor, so innovation is needed to promote and expand the marketing target, to overcome this problem, the use of modern technology such as E-Commerce can be the best innovation.

E-Commerce is a trading system that is carried out by utilizing the development of telecommunications technology using internet media. Designing an E-Commerce information system in this study applies Responsive Web-based E-Commerce. The design of this information system was designed using the PHP programming language, and MySql as a database.

\section{Rudimentary}

\subsection{System}

A network of procedures that are interconnected, gather together to carry out an activity or to complete a certain goal [1].

\subsection{Information}

Data that has been put in a more meaningful and useful context that is communicated to the recipient to be used in decision making [2].

\subsection{Website}

The web is one application that contains multimedia documents (text, images, sound, animation, video) in it using the HTTP (hypertext transfer protocol) [4]. 


\subsection{PHP}

Hypertext preprocessor (PHP) is a web programming language in the form of a script that can be integrated with HTML [5].

\subsection{MySql}

My Structure Query Language (MySql) is an application or system for managing databse or data management. To store all information on computers using data [6].

\section{Research Methodology}

\subsection{Data Collection}

Data collection in this study uses several methods including:

\subsubsection{Observation}

Observation is carried out by observing directly the object to be studied regarding the problems to be discussed, namely by visiting the location of the object to see and observe the activities between the customer and the manufacture of the product.

\subsubsection{Interview}

Interviews conducted at several home tailors in Palembang on April 30, 2019, concluded that the problems faced were promotions that were not maximized due to the absence of promotional media such as media websites.

\subsubsection{Library}

This study discusses website design as a promotion and marketing media to help home tailors SMEs to market services and products to the wider community. From some of the above explanations, it can be concluded that online marketing media is indeed more efficient because it is cheap and also has wider market coverage [3].

\subsection{System Development Method}

The system development method in designing websites as a promotional media for these home-based SMEs using a waterfall model or waterfall model provides a sequential or sequential software flow approach [7].

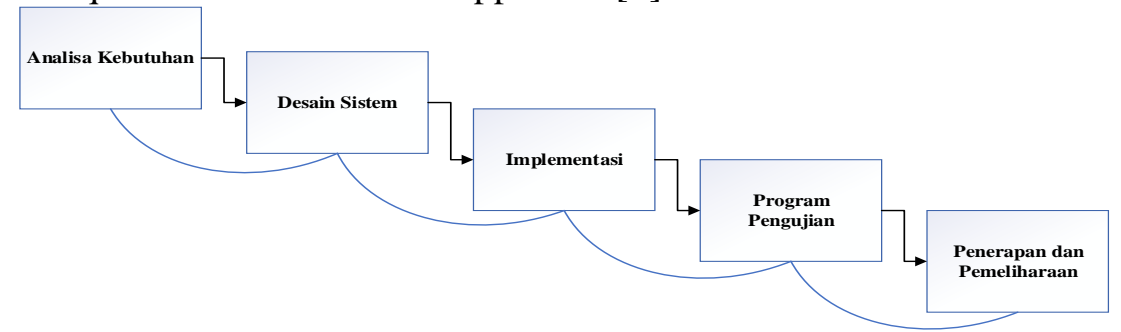

Figure 1. Waterfall Development Method

Waterfall method has 5 stages, namely:

a. Needs Analysis : Analyzing system requirements functionally such as features or processes that will be provided by the system as well as nonfunctional requirements such as system access, system ease of use, and system reliability, and system security factors.

b. System Design : determine the system design, layout, contents and color combinations that will be used on the system.

c. Implementasi : Application of system design results into programming languages.

d. Program Testing : System testing is done using the blackbox testing method 
e. Implementation and Maintenance : Implemented and ascertained whether the system is running well then the system maintenance stage regarding correction of errors that might occur.

\section{Result and Discussion}

\subsection{System planning}

\subsubsection{Flowchart Registration, Customer, and Admin}

Flowchart is a flow chart with certain symbols that describe the sequence of processes withdetails and the relationship between the process of instruction and other processes in a program.

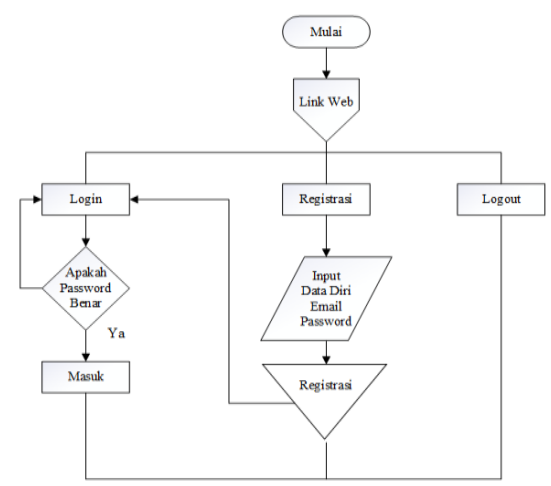

Figure 2. Registration Flowchart

From the picture above, the water chart shows the system flow for the registration page if the customer does not have an e-mail and password to $\log$ in to the system, starting from displaying the login page and on the login page there will be a login option if you have registered and have an e-mail and password registered on system or click registration if you do not have an e-mail and password that has not been registered on the system, in the registration menu will display a column for entering personal data (name, complete address, cellphone number and e-mail and password) where this data will be saved to the system database. go to the login page again and enter and exit the menu to return to the start page, namely the login page.

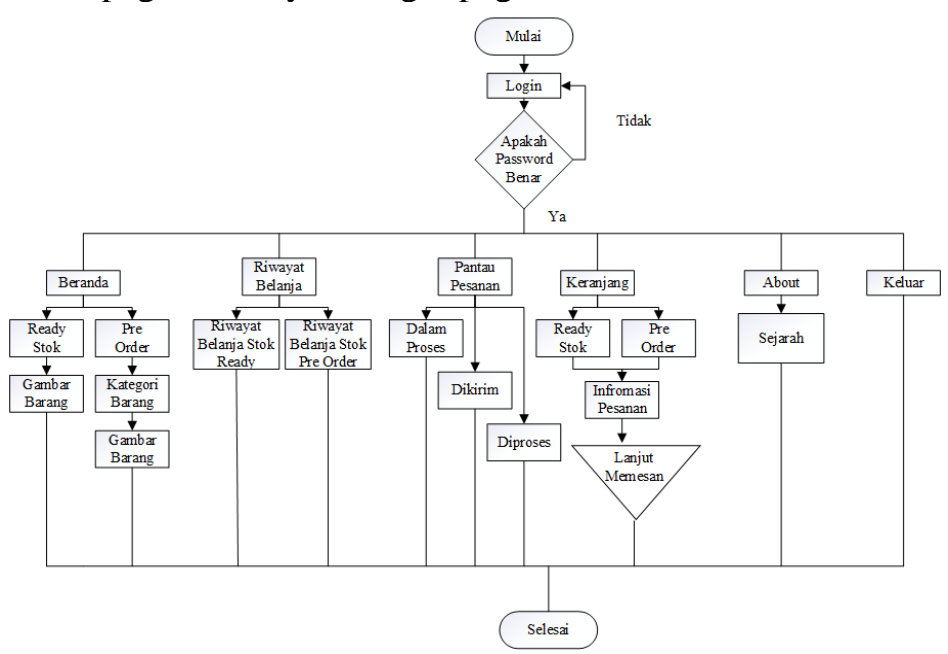

Figure 3. Customer Flowchart 
From the picture above shows the system flow that will be built in a sales application for the customer, where it starts from the login menu as the customer, by entering the correct user name and password, after the login will enter the home menu where the two menus will display ready item catalog menu and item catalog menu pre order, on the item catalog ready menu will display all ready-made items, while in the pre order item catalog menu will display item categories. On the shopping history menu will display a history of ready shopping and pre order. On the menu monitor the order will display order information whether in the process, has been processed, or already in the delivery. On the basket menu displays a list of ready orders and pre orders to proceed to the order process. On the about menu will display the history of the store, and on the exit menu will return to the login page.

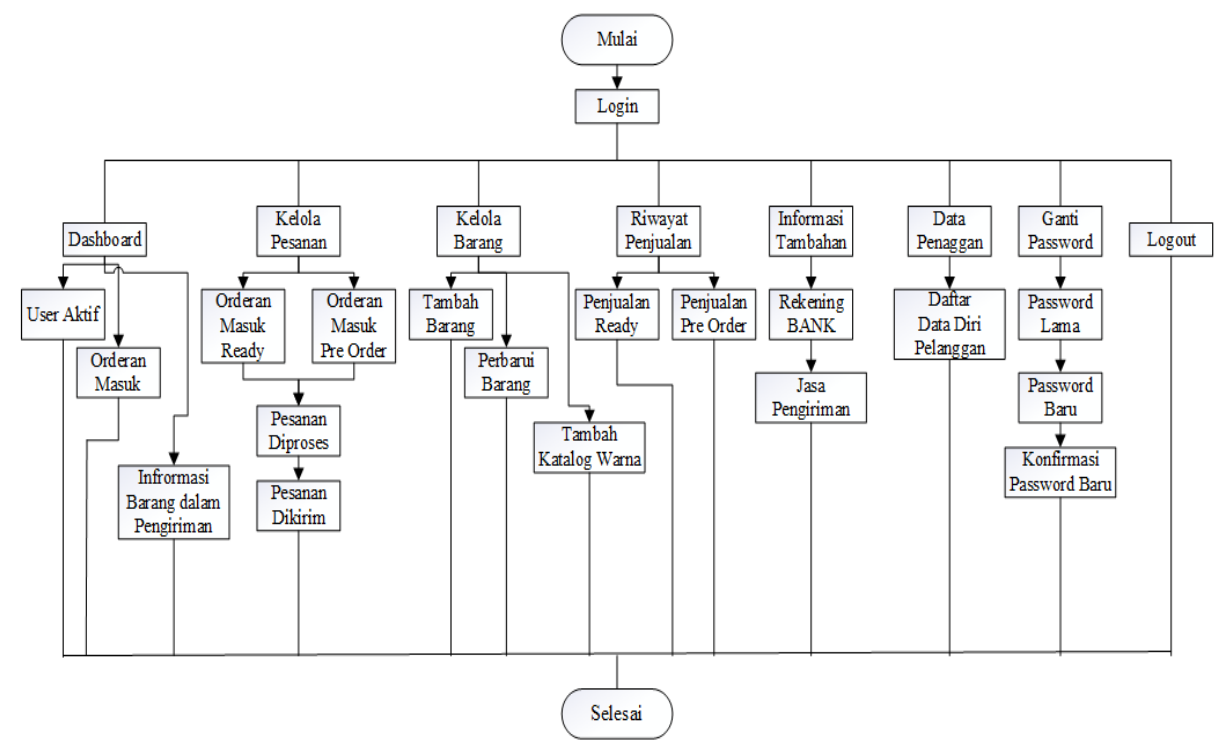

Figure 4. Admin Flowchart

From the picture above shows the system flow that will be built in a sales application for admin, where it starts from the login menu as an admin, by entering the user name and admin password which have been obtained from the system, after logging in it will go to the Dashboard menu, as well as submenu others such as Manage Orders, Manage Goods, Sales History, Additional Information, Customer Data, Change Password, and Logos. In the Dashboard menu will display the number of active users / customers, orders that enter, and information on items that have been shipped. On the Manage Goods menu, the Order Ready Stock and Pre Order are displayed, where the admin can follow up on incoming orders so that the admin can input the total order, so customers can pay the order and send proof of payment, then the admin confirms payment and performs shipping goods after that the admin will input the delivery receipt. In the item management menu, admin can add items, update, and add color catalogs of items. On the sales history menu will display the sales history of ready goods and goods pre order in the form of a table. In the additional information menu displays the bank account number input menu, the delivery service provided and the home photo update menu. On the customer data menu will display the customer's personal data in the form of a table. The password change menu will provide a password change menu, starting from the old password input, new password and new password confirmation, and in the logout menu to return to the initial login screen. 


\subsection{Implementation}

\subsubsection{Web Implementation}

Designing websites as promotional media and marketing services and products for home tailors SMEs in order to improve service quality and expand marketing targets.

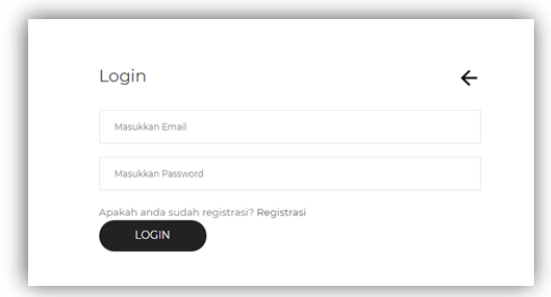

Figure 5. Implementation of the login page

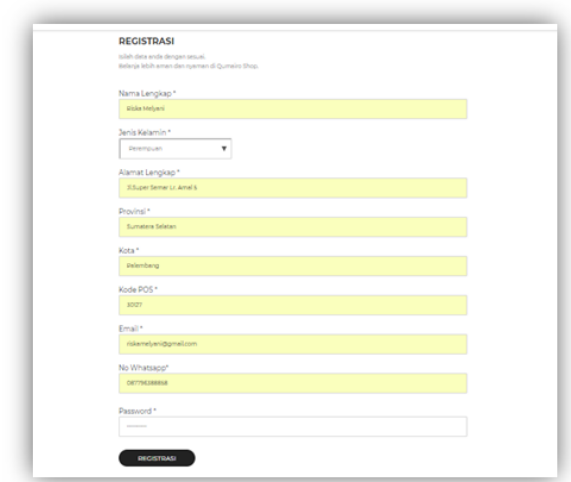

Figure 6. Implementation of Registration Page

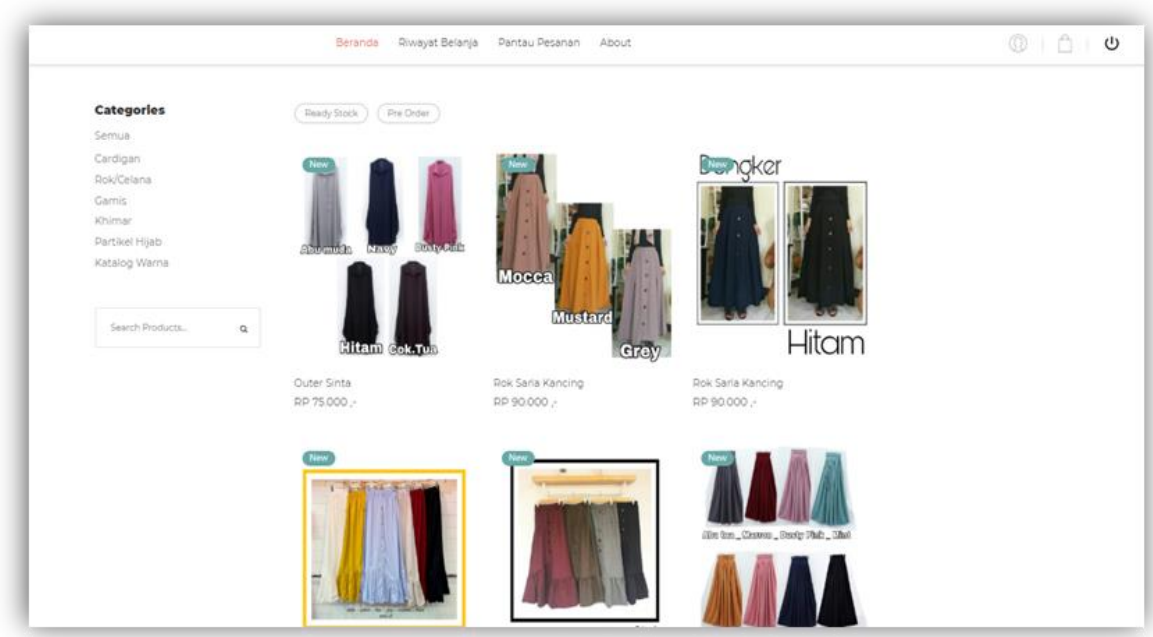

Figure 7. Implementation of the Customer Home Page

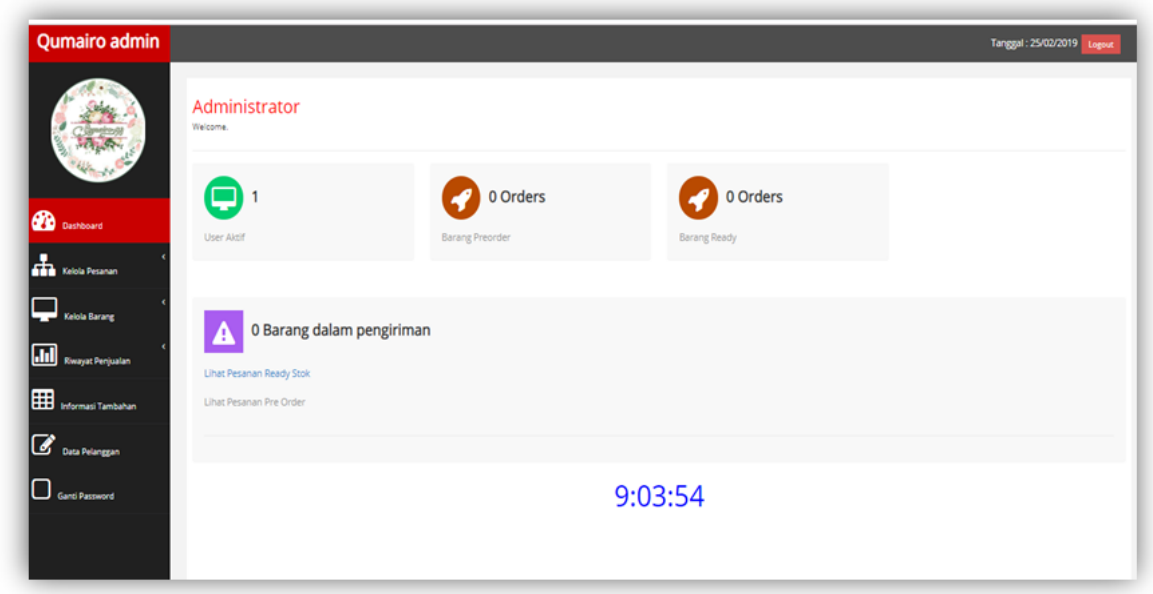

Figure 8. Implementation on the Admin Dashboard Page 


\section{Conclusion}

The results of responsive web-based E-Commerce information system design for home-based SMEs in Palembang are the design of this system was made to make it easier for home-tailor SMEs to market the results of stitching products and offer stitch booking services using a website that has been designed according to the needs of SMEs and customers.

For further development this design can further maximize the security of the existing system. This e-Commerce information system which is still based on responsive web can be further developed into a mobile mobile application that can be installed on mobile devices, even though this design is responsive web-based which can also be accessed on browsers on mobile mobile phones, as well as web displays. responsive will adjust the appearance of the mobile used.

\section{References}

[1] H.M, Jogiyanto (2005). Analisis dan Desain Sistem Iformasi. Yogyakarta: Penerbit Andi.

[2] H.M, Jogiyanto (2005). Sistem Informasi Berbasis Komputer. BPFE-Yogyakarta: Yogyakarta.

[3] Triono (2012). Jurnal Ilmiah Pembuatan Media Promosi dan Pemasaran Produk Berbasis di CV. Tanjung Pinang Motor Pacitan. Solo: Universitas Surakarta.

[4] Wibisono \& Susanto. 2015. Perancangan Website Sebagai Media Informasi Dan Promosi Batik Khas Kabupaten Kulonprogo. Evolusi, 3(2), 65

[5] Prayitno, Agus. 2015, Pemanfaatan Sistem Informasi Perpustakaan Digital Berbasis Website Untuk Para Penulis. Indonesian Journal on Software Engineering. 1(1), 2.

[6] Sugiyanto. 2013. Pembuatan Website Profil Sekolah Menengah Kejuruan Pembangunan Nusantara Gabus Grobogan. seruniid.unsa.ac.id. 2(1), 57.

[7] A. S, Rosa dan M Shalahuddin, Rekayasa Perangkat Lunak Terstruktur dan Berorientasi Objek. Bandung: Informatika, 2013.

\section{Authors}

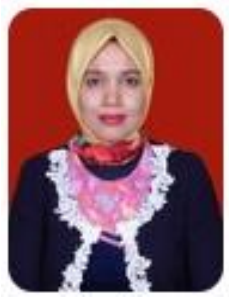

$1^{\text {st Author }}$

Irma Salamah

Teknik Telekomunikasi

Politeknik Negeri Sriwijaya

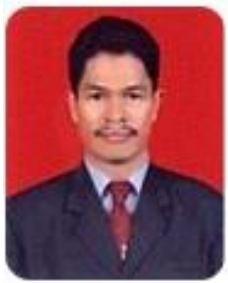

$2^{\text {nd }}$ Author

Teknik Telekomunikasi

Politeknik Negeri Sriwijaya
Ciksadan

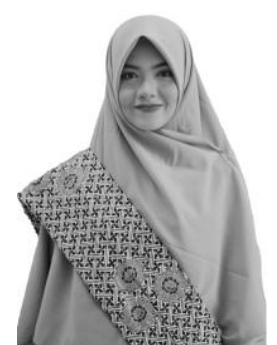

$3^{\text {rd Author }}$

Riska Melyani

Student

Teknik Telekomunikasi

Politeknik Negeri Sriwijaya 